\title{
Differential Diagnosis of Parasitic Diseases of the Gastrointestinal Tract Using Artificial Neural Networks
}

U N Musevi

Azerbaijan State University of Oil and Industry, Baku AZ1010, Azerbaijan.

Corresponding Author: U N Musevi, Azerbaijan State University of Oil and Industry, Baku AZ1010, Azerbaijan.

\section{Received Date: 25 September 2021 | Accepted Date: 21 October 2021 | Published Date: 26 October 2021}

Citation: U N Musevi. (2021). Differential Diagnosis of Parasitic Diseases of the Gastrointestinal Tract Using Artificial Neural Networks. Journal of Clinical and Laboratory Research. 3(5); DOI:10.31579/2768-0487/053

Copyright: (c) 2021 U N Musevi. This is an open-access article distributed under the terms of the Creative Commons Attribution License, which permits unrestricted use, distribution, and reproduction in any medium, provided the original author and source are credited.

\begin{abstract}
Disorders of the functional state of the gastrointestinal tract associated with the influence of various parasites are considered. The symptoms of diseases caused by parasites and their location in the gastrointestinal tract are given. The possibility of using neural network technology in diagnosing illnesses as a result of the influence of various parasites is estimated. The structure of the neural network is given, indicating the set of inputs and outputs, as well as the result of its training. For the created neural network, test results for the respective symptoms and disease prediction results for these symptoms were obtained.
\end{abstract}

Key Words: gastrointestinal tract; parasites; symptoms; neural network; structure; testing; prediction; error

\section{Introduction}

Often, a violation of the functional state of the gastrointestinal tract (GIT) is associated with the influence of various parasites. Parasites have a more complex structure and have well-oiled defense mechanisms directed against the human immune system (encapsulation, antigenic mimicry, antigenic "drift," inactivation of enzymes and biologically active substances, etc.), which allows them to exist for a long time in various human organs and tissues ... Also, there are objective difficulties in identifying, isolating, and obtaining immunoreagent specific antigens of parasites.

Therefore, for example, the immune response in giardiasis is for the most part due not to the surface proteins of the parasite, but to antigens that enter the human body along with the products of their vital activity. Thus, in the laboratory diagnosis of many pests, serological research methods are only of auxiliary value [1].

The World Health Organization has proven that $95 \%$ of humanity has a variety of parasites in the body. These living organisms are not as harmless and safe as it might seem in the first place. Most of them are localized in the organs of the gastrointestinal tract (the eggs of the worms get here along with contaminated water and food). Still, there are also socalled extra intestinal forms of invasion - parasites can live in the lungs, heart and even the human brain [2].

\section{Immune disorders and disease symptoms}

Parasites weaken the immune system, lowering the release of immunoglobulin, and their presence constantly stimulates the system's response and, over time, can loosen this vital immune mechanism, opening the way for bacterial and viral infections to enter the body.

These symptoms are just a few of them. In reality, the symptoms of diseases caused by parasites in the digestive tract are more extensive. The most challenging thing about this is that these symptoms of different infections are very close and require additional techniques to clarify the diagnosis.

Probable etiological factors of gastrointestinal tract dysfunction are mainly parasites: Entamoeba, Giardia lamblia, Balantidium colitis, Ascaris lumbricoides, Enterobius vermicularis, Taenia solium (saginata), Strongyloides stercoralis, Cryptosporidium parvum [3].

\begin{tabular}{|l|l|l|}
\hline Types of parasites & Habitat & Source \\
\hline Entamoeba & large intestine & {$[4]$} \\
\hline Giardia lamblia & small intestine & {$[5]$} \\
\hline Balantidium colitis & large intestine & {$[6]$} \\
\hline Ascaris lumbricoides & small intestine & {$[7]$} \\
\hline
\end{tabular}




\begin{tabular}{|l|l|c|}
\hline $\begin{array}{l}\text { Enterobius } \\
\text { vermicularis }\end{array}$ & $\begin{array}{l}\text { cecum or appendix, small } \\
\text { intestine, colon }\end{array}$ & {$[8]$} \\
\hline Taenia solium (saginata) & small intestine & {$[9]$} \\
\hline $\begin{array}{l}\text { Strongyloides } \\
\text { stercoralis }\end{array}$ & $\begin{array}{l}\text { duodenum, lean } \\
\text { intestine }\end{array}$ & {$[10]$} \\
\hline Cryptosporidium parvum & small intestine & {$[11]$} \\
\hline Echinostoma & small intestine & {$[12]$} \\
\hline
\end{tabular}

Table 1: Location of parasites in the gastrointestinal tract

Colitis is an inflammation of the colon, observed in several diseases, namely, in chronic inflammatory bowel diseases, pseudomembranous colitis, and infections caused by bacteria, parasitic protozoa (amoeba) and viruses. Irritable bowel syndrome, otherwise called mucosal or spastic colitis, is not associated with inflammation of the colon, although it has similar symptoms [13]

The causative agent of giardiasis in humans is Lamblia intestinalis (Giardia intestinalis, Giardia lamblia). Giardiasis is an adequately widespread invasion throughout the world that affects all age groups, but children suffer from this disease more often than others [14].

Balantidium colitis is a type of ciliates parasitizing in the large intestine of some mammals: as a rule, in pigs, less often in rats, dogs, and also in humans. It causes a disease called balantidiasis or ciliated dysentery [6]

Ascariasis - intestinal invasion from the group of nematodes, the causative agents of which are roundworms (Ascaris lumbricoides).
Ascaris parasitizes in the small intestine [7].

Enterobiasis is an intestinal invasion by the pinworm Enterobius vermicularis, usually found in children [15].

Cysticercosis is the most common parasitic disease of the central nervous system. The invasion of the central nervous system by the larvae of the pork tapeworm Taenia solium occurs when eating food contaminated with helminth eggs [16].

Strongyloidiasis is an invasion caused by Strongyloides stercoralis [15].

Cryptosporidiosis is a parasitic disease caused by protists of the genus Cryptosporidium from the Apicomlex type. Cryptosporidiosis, as a rule, manifests itself as an acute and short-term infection and is spread by the nutritive route, often through contaminated water [17].

Echinostoma infects the gastrointestinal tract in humans and can cause a disease known as echinostomes [18].

\begin{tabular}{|c|c|c|c|c|c|c|c|c|c|c|c|}
\hline \multirow[t]{2}{*}{ No } & \multirow[t]{2}{*}{ Symptoms } & \multirow{2}{*}{$\begin{array}{l}\text { Shorteni } \\
\text { ng }\end{array}$} & \multicolumn{9}{|c|}{ Gastrointestinal parasites } \\
\hline & & & $\begin{array}{l}\text { Entamoe } \\
\text { ba }\end{array}$ & $\begin{array}{l}\text { lambli } \\
\text { a }\end{array}$ & $\begin{array}{l}\text { coliti } \\
\text { S }\end{array}$ & $\begin{array}{l}\text { lumbricoi } \\
\text { des }\end{array}$ & $\begin{array}{l}\text { Enterobiu } \\
\mathrm{S} \\
\text { vermicula } \\
\text { ris }\end{array}$ & $\begin{array}{l}\text { solium(sa } \\
\text { gi) }\end{array}$ & $\begin{array}{l}\text { sstercora } \\
\text { lis }\end{array}$ & $\begin{array}{l}\text { Cryptospo } \\
\text { rid }\end{array}$ & $\begin{array}{l}\text { Echinosto } \\
\text { ma }\end{array}$ \\
\hline 1 & Intensity invasions & II & + & & & + & + & & & & + \\
\hline 2 & Violations intestinal peristalsis & VIP & + & & & & + & & & & \\
\hline 3 & Immunodeficiency & ID & + & & & & & & + & + & \\
\hline 4 & Fasting & Fast & + & & & & + & & & & \\
\hline 6 & Perforation intestines & $\mathrm{PI}$ & + & & + & & & & & & \\
\hline 7 & Intestinal bleeding & IB & + & & + & + & & & + & + & + \\
\hline 8 & $\begin{array}{l}\text { Tumor Over growth in the wall } \\
\text { of the large intestine Quality } \\
\text { control department }\end{array}$ & TLI & & & & & & & & & \\
\hline 9 & Amoebic intestinal structure & AIS & + & & & & & & & & \\
\hline 10 & $\begin{array}{l}\text { Pain, bloating and } \\
\text { rumbling in the stomach }\end{array}$ & PBRSt & & + & + & & & & + & & + \\
\hline 13 & $\begin{array}{l}\text { Magnification of the amount } \\
\text { of undigested fat in feces }\end{array}$ & MFF & & + & & & & & & + & \\
\hline 14 & Dysbacteriosis & $\mathrm{DB}$ & & + & & & & & & & \\
\hline 15 & Loss of appetite & LA & & + & & + & + & + & + & & \\
\hline 16 & Allergy & Aller & & + & & & + & & + & & \\
\hline 17 & Diarrhea & Diar & & & + & & & + & + & & + \\
\hline 18 & $\begin{array}{l}\text { Spasm and soreness of the } \\
\text { large intestine }\end{array}$ & SBLI & & & + & + & + & & & & \\
\hline 19 & Fever & Fev & & & + & & & & & + & \\
\hline 20 & Slimming & Slim & & & + & & & & + & & + \\
\hline 21 & Irritation peritoneum & IP & & & + & & & + & & & \\
\hline 22 & Insomnia & Inso & & & & & + & & & & \\
\hline 23 & Stomach pains & StP & & & & & & & & + & \\
\hline 24 & Diarrhea & Diar & & & & & & & & + & + \\
\hline
\end{tabular}




\begin{tabular}{|l|l|l|l|l|l|l|l|l|l|l|l|l}
\hline 25 & Disease associated with & Colitis & $\begin{array}{l}\text { Giardi } \\
\text { asis }\end{array}$ & $\begin{array}{l}\text { Bala } \\
\text { ntidia } \\
\text { sis }\end{array}$ & Ascariasis & $\begin{array}{l}\text { Enterobias } \\
\text { is }\end{array}$ & $\begin{array}{l}\text { Cysticerco } \\
\text { sis }\end{array}$ & $\begin{array}{l}\text { Strongyl } \\
\text { oidosis }\end{array}$ & $\begin{array}{l}\text { Crypospor } \\
\text { itosdio }\end{array}$ & $\begin{array}{l}\text { Echinosto } \\
\text { mosis }\end{array}$ \\
\hline
\end{tabular}

Table 2: Symptoms and diseases associated with major gastrointestinal parasites

A neural network model for predicting gastrointestinal diseases caused by parasites

Artificial neural networks are effectively used in the diagnosis of various diseases $[19,20]$. Neural network technologies are also used for the diagnostic of diseases of the gastrointestinal tract, for example, for the differential diagnosis of liver diseases [21] and in predicting the development of abdominal sepsis in patients with severe acute pancreatitis $[22,23]$.

The experiment was carried out on a NeuroPro network emulator. NeuroPro0.25 beta version allows you to implement the following basic operations:

- the creation of neuroprojects;

- connect data files with a neuroproject;

- adding layer architectures to neural projects from 1 to 10 layers, with up to 100 neurons in each;

- train a neural network to solve forecasting and classification problems;

- testing of a neural network based on database files, calculating the significant indicators of input signals;
- simplify the neural network;

- selection of learning algorithms, determination of forecasting for a given accuracy, etc.

\section{Setting up an experiment}

A neural network that determines the prognosis of diseases using the symptoms of diseases.

For the experiment, we select the symptoms of various gastrointestinal forgetfulness, progressing with parasites. Twenty-four indications were selected (at the request of doctors, the number of symptoms can be increased, since these systems are open) and nine diseases (it should be noted that the number of illnesses created by parasites is quite large, the most common of them were selected) (table 2). For the experiment, a neural network simulator NeuroPro 0.25 , was used.

The input parameters of the neural network are the symptoms shown in Table 2, the set of inflows includes 9 varieties, and the output of the net system will be the solution of the neural network according to the training rules. Figure 1 shows a neural network corresponding to the first variant of the experiment.
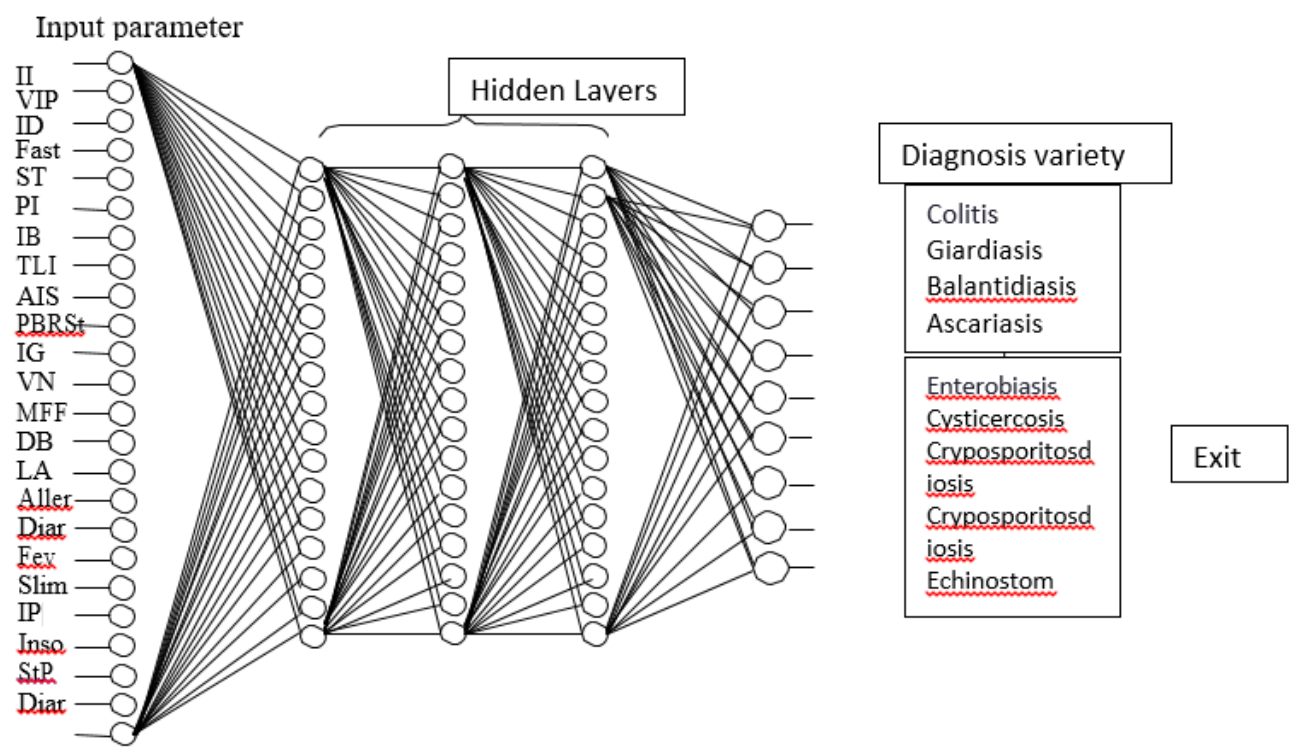

Figure1: Neural network corresponding to the first variant of the experiment

\begin{tabular}{|l|l|l|}
\hline No & Symptoms & $\begin{array}{l}\text { Relevant network } \\
\text { inputs }\end{array}$ \\
\hline 1 & Intensity invasions & N1 \\
\hline 2 & Violations intestinal peristalsis & N2 \\
\hline 3 & Immunodeficiency & N3 \\
\hline 4 & Fasting & N4 \\
\hline 5 & Stress & N5 \\
\hline 6 & Perforation intestines & N7 \\
\hline 7 & Intestinal bleeding & N8 \\
\hline 8 & Tumor overgrowth in the wall of the large intestine & N9 \\
\hline 9 & Amoebic intestinal structure & N10 \\
\hline 10 & Pain, bloating and rumbling in the stomach of BWU & \\
\hline
\end{tabular}




\begin{tabular}{|l|l|l|}
\hline 11 & Increased gassing & N11 \\
\hline 12 & Vomiting, nausea & N12 \\
\hline 13 & Magnification of the amount of undigested fat in feces & N13 \\
\hline 14 & Dysbacteriosis & N14 \\
\hline 15 & Loss of appetite & N15 \\
\hline 16 & Allergy & N16 \\
\hline 17 & Diarrhea & N17 \\
\hline 18 & Spasm and soreness of the large intestine & N18 \\
\hline 19 & Fever & N19 \\
\hline 20 & Slimming & N20 \\
\hline 21 & Irritation peritoneum & N21 \\
\hline 22 & Insomnia & N22 \\
\hline 23 & Stomach pains & N23 \\
\hline 24 & Diarrhea & N24 \\
\hline
\end{tabular}

Table 3: Multiple network inputs with corresponding symptoms

\begin{tabular}{|l|l|l|}
\hline No & Symptoms & Relevant network outputs \\
\hline 1 & Colitis & N25 \\
\hline 2 & Giardiasis & N26 \\
\hline 3 & Balantidiasis & N27 \\
\hline 4 & Ascariasis & N28 \\
\hline 5 & Enterobiasis & N29 \\
\hline 6 & Cysticercosis & N30 \\
\hline 7 & Strongyloidosis & N31 \\
\hline 8 & Cryposporitosdiosis & N32 \\
\hline 9 & Echinostomosis & N33 \\
\hline
\end{tabular}

Table 4: Outputs of the neural network with corresponding diseases

After displaying the input and output parameters of the network, the network is trained.

The analysis shows that the most optimal algorithm for learning a multilayer perceptron is the back propagation algorithm [24].

To test the created neural network, selected symptoms were chosen (Table 5).

\begin{tabular}{|l|l|}
\hline Corresponding network inputs & Symptoms \\
\hline N1 & Intensity invasions \\
\hline N5 & Stress \\
\hline N6 & Bowel perforation \\
\hline N7 & Intestinal bleeding \\
\hline N10 & $\begin{array}{l}\text { Pain, bloating and rumbling } \\
\text { in the stomach }\end{array}$ \\
\hline N11 & Increased gassing \\
\hline N14 & Dysbacteriosis \\
\hline N17 & Diarrhea \\
\hline N20 & Slimming \\
\hline N21 & Peritoneal irritation \\
\hline
\end{tabular}

Table 5: Input symptoms for testing

Table 6 shows the results of a neural network for predicting diseases by symptoms.

\begin{tabular}{|l|l|l|l|}
\hline No & Symptoms & Relevant network outputs & Network forecast \\
\hline 1 & Colitis & N25 & -0.1516073 \\
\hline 2 & Giardiasis & N26 & 0.1060389 \\
\hline 3 & Balantidiasis & N27 & 0.3889541 \\
\hline 4 & Ascariasis & N28 & -0.160576 \\
\hline 5 & Enterobiasis & N29 & 0.1938157 \\
\hline 6 & Cysticercosis & N30 & -0.1561767 \\
\hline 7 & Strongyloidosis & N31 & 0.3709661 \\
\hline 8 & Cryposporitosdiosis & N32 & 0.07566229 \\
\hline 9 & Echinostomosis & N33 & 0.4827752 \\
\hline
\end{tabular}

Table 6: Neural network results 


\section{Conclusion}

Thus, an efficient type of structure of an artificial neural network designed to solve problems of medical diagnostics and prognosis is a perceptron with sigmoid activation functions, the input of which is information about the symptoms of a patient's diseases, and the output is a diagnosis of the disease. According to the results obtained by the neural network, it is possible to confidently clarify the illness that corresponds to the "Echinostomosis" output, created by parasites of the small intestine, which as a result, leads to a violation of the functional state of the gastrointestinal tract.

\section{References}

1. S S.S. Kozlov, V.S. Turitsin, A.V. Laskin. (2011). Diagnostics of parasitoses. Modern myths. Journal of Infectology, Volume 3 (1):64-68.

2. Intestinal parasites

3. Diagnosis of parasitic infections

4. http: //www.iacmac.ru/iacmac/ru/pub/metod/amebiaz/

5. Giardia lamblia, antigen

6. https://ru.wikipedia.org/wiki/Balantidium_coli [Balantidium coli]

7. https: //ru.wikipedia.org/wiki/Human_askaris

8. 8. https: //ru.wikipedia.org/Enterobiasis [Enterobius vermicularis LifeCycle]

9. https: //ru.wikipedia.org/Bull_chain

10. https://ru.wikipedia.org/wiki/Strongyloides_stercoralis [Strongyloides stercoralis]

11. https: //www.monographies.ru/en/book/section?id=9029
12. https: //ru.wikipedia.org/wiki/Human_parasite_list

13. http: //santegra-rus.ru/kolit.html[ Colitis]

14. http: //ngmu.ru/cozo/mos/article/text_full.php?id=1948 [PECULIARITIES OF RR, QT AND TQ-PERIODS DISPERSION IN ADOLESCENTS DURING ORTHOSTATIC TEST]

15. https: //www.msdmanuals.com/ru/

16. http: //www.pirogovcenter.ru/specialist/diseases/detail.php?ID $=584$

17. https: //ru.wikipedia.org/wiki/Cryptosporidioz

18. https://ru.qwe.wiki/wiki/Echinostoma

19. M.V. Vyucheyskaya, I. N. Krainova, A. V. Gribanov. (2018). Neural network technologies in the diagnosis of diseases // Journal of Biomedical Research6 (3): 284-294.

20. I.G. Churyumov. Medical decision making system using a neural network.

21. Maclin P.S., Dempsey J. (1992). Using an Artificial Neural Network to Diagnose Hepatic Masses.Journal Medical Systems.16 (5):215-225.

22. Kazmierczak S.C., Catrou P.G., Van Lente F. (1993). Diagnostic Accuracy of Pancreatic Enzymes Evaluated by Use of Multivariate Data Analysis. Clinical Chemistry. 39 (9): 19601965.

23. P.I., Mironov, I.I. Lutfarakhmanov, I.Kh. Ishmukhametov, V.M.Timerbulatov. (2008). Artificial neural networks in predicting the development of sepsis in patients with severe acute pancreatitis // Annals of Surgical Hepatology. 13 (2): $85-$ 89.

24. S. Khaikin. (2006). Neural Networks: A Complete Course. - M.: Publishing house "Williams".

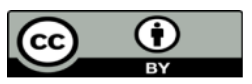

This work is licensed under Creative Commons Attribution 4.0 License

To Submit Your Article Click Here: Submit Manuscript

DOI: $10.31579 / 2768-0487 / 053$
Ready to submit your research? Choose Auctores and benefit from:

$>$ fast, convenient online submission

$>$ rigorous peer review by experienced research in your field

$>$ rapid publication on acceptance

$>$ authors retain copyrights

$>$ unique DOI for all articles

$>$ immediate, unrestricted online access

At Auctores, research is always in progress.

Learn more auctoresonline.org/journals/journal-of-clinical-andlaboratory-research 